\title{
Síndrome 'Luvas-e-Peúgas’ em Doente com Infecção por VIH
}

\section{‘Gloves and Socks’ Syndrome in a HIV Patient}

\author{
Diana PÓVOAS $\rrbracket^{1}$, Cândida FERNANDES², Fernando MALTEZ \\ Acta Med Port 2016 Oct;29(10):674-674 - http://dx.doi.org/10.20344/amp.7017
}

Palavras-chave: Dermatoses da Mão; Dermatoses do Pé; Infecções por Parvoviridae; Infecções por VIH; Parvovirus B19 Humano; Síndrome.

Keywords: Foot Dermatoses; Hand Dermatoses; HIV Infections; Parvoviridae Infections; Parvovirus B19, Human; Syndrome.

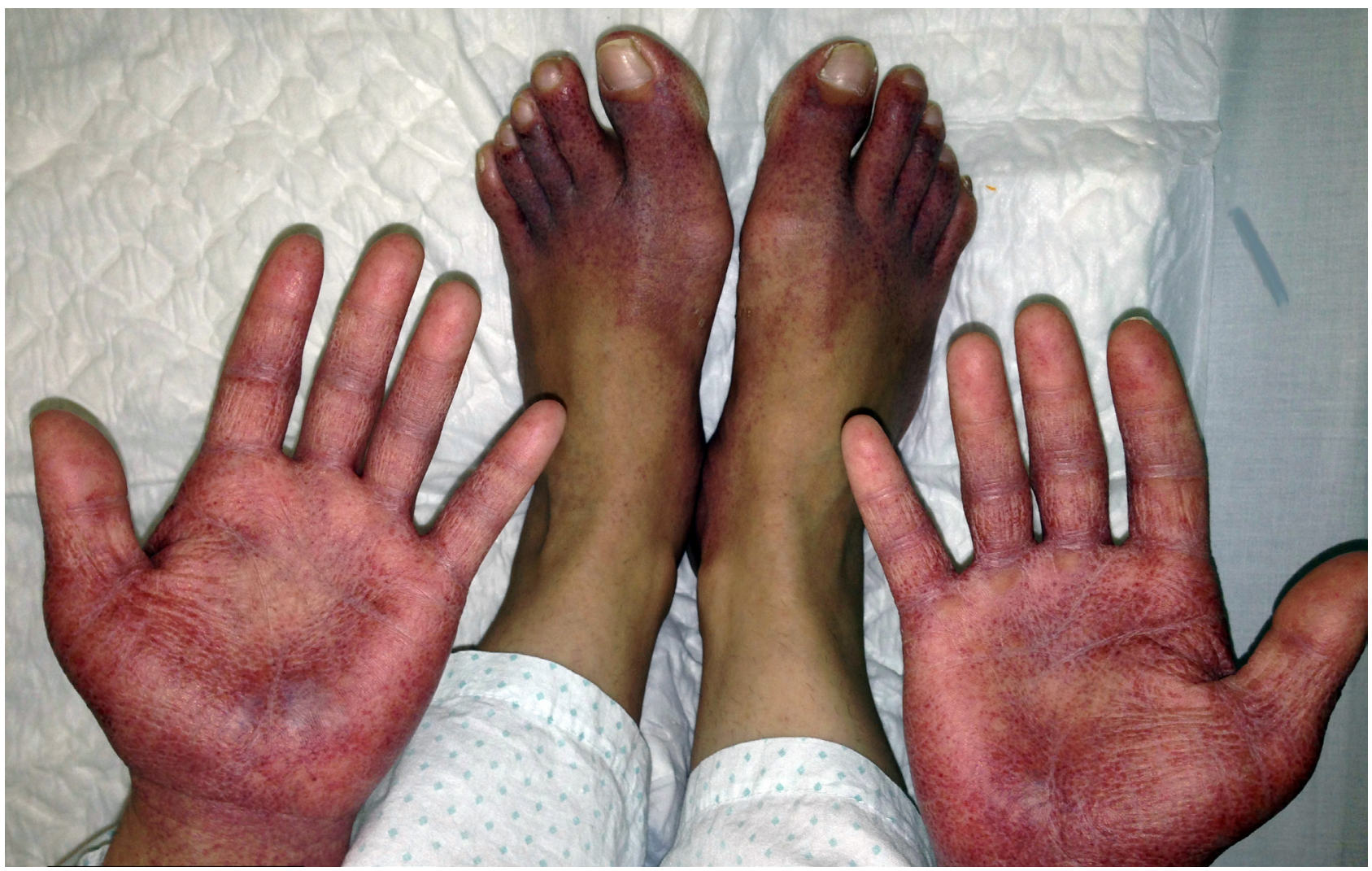

Figura 1 - Dermatose eritemato-purpúrica palmo-plantar em 'luva' e 'meia'

A síndrome luvas-e-peúgas é habitualmente uma manifestação aguda da infecção por parvovírus B19 no adulto imunocompetente, sendo raramente descrita na infecção VIH/SIDA. A este propósito, descreve-se o caso de doente de 39 anos com infecção por VIH-1 conhecida, sob terapêutica antirretrovírica com carga viral de $\mathrm{VIH}-1$ indetectável, contagem de linfócitos TCD4+ 900 cells/ $\mu \mathrm{L}$, internada por quadro com cinco dias de evolução de dermatose bilateral e simétrica, purpúrica e edematosa dos pés e mãos, com limite superior abrupto, acompanhada de artralgias intensas e mal-estar geral, precedida de odinofagia, tossícula não produtiva e rinorreia anterior serosa. À observação constatou-se presença de dermatose eritemato-purpúrica palmo-plantar em 'luva' e 'meia', com envolvimento do sulco internadegueiro e axilar bilateral. (Fig. 1) Os exames realizados mostraram anemia ( $\mathrm{Hb} 9,9 \mathrm{~g} / \mathrm{dL})$, discreta eosinofilia $\left(0,61 \times 10^{9} / \mathrm{L}, 13 \%\right)$, a par de serologia positiva para parvovírus B19 com imunoglobulina M positiva, imunoglobulina $\mathrm{G}$ negativa e polymerase chain reaction positiva para parvovírus B19 em zaragatoa da orofaringe. A doente evoluiu favoravelmente.

1. Serviço de Doenças Infecciosas. Hospital de Curry Cabral. Centro Hospitalar de Lisboa Central. Lisboa. Portugal.

2. Serviço de Dermatovenereologia. Hospital de Curry Cabral. Centro Hospitalar de Lisboa Central. Lisboa. Portugal.

$\triangle$ Autor correspondente: Diana Póvoas.d.povoas@gmail.com

Recebido: 20 de setembro de 2015 - Aceite: 29 de dezembro de 2015 | Copyright @ Ordem dos Médicos 2016 